\title{
Evaluation of the use of prefabricated bridge elements with Design for Manufacture and Assembly (DfMA) criteria
}

\author{
Yan Purnomo Safaa ${ }^{1, *}$, Jati Utomo Dwi Hatmoko $^{2}$, and Bambang Purwanggono ${ }^{3}$ \\ ${ }^{1}$ The Institution of Engineers, Jakarta, Indonesia \\ ${ }^{2}$ Department of Civil Engineering, Faculty of Engineering, Diponegoro University, Semarang, Indonesia \\ ${ }^{3}$ Department of Industrial Engineering, Faculty of Engineering, Diponegoro University, Semarang, Indonesia
}

\begin{abstract}
The increasing need for bridge infrastructure in Indonesia requires an efficient and lean construction process. The aim of this research to evaluate the use of precast concrete elements on bridges based on the Design for Manufacture and Assembly (DfMA) criteria. DfMA is a principle design that considers the process of manufacture and assembly components based on the following criteria, i.e., simplificity of design, number of components, standardization on elements or material and ease of handling. Analytical Hierarchy Process (AHP) is used to determine the weights for each criteria. Data were collected through observations on a bridge project, interviews with engineers and questionnaires. A typical girder and slab bridge is used as an object for DfMA-based evaluation. The results of evaluation design of prefabricated components to recommend some that are suitable for use in bridge construction. The last case study was taken to one of the bridge construction projects on the newly completed highway is done to identify the prefabricated components used. Bridge analysis and re-design are carried out with the DfMA concept, including costs incurred, resource scheduling and discussions of project risk. The results of analysis with simulation design giving efficiency $28,83 \%$ simplificity of design; $8,74 \%$ number of components and standardization on elements or materials; $25 \%$ ease of handling; $51,53 \%$ assembly time; $23,39 \%$ cost of work and $18,87 \%$ duration time. Finally, the level of risk of work received such as weather conditions and work safety is reduced. In closing, recommendations were given for further DfMA development.
\end{abstract}

\section{Preliminary}

The availability of infrastructure is an important and vital aspect to accelerate the national development process. Increasing population parallel with demand roads and bridges. On the traditional bridge construction it is often criticized for being inefficient and unsafe [1]. To overcome this through the Accelerated Bridge Construction (ABC) program, which is a construction management system with the use of more prefabricated technology in the implementation process [2]. Applying prefabrication with the main characteristics of assembly on bridge elements is an effort to standardize products or components through the factory [3].

The design stage plays a crucial role in determining the resources, costs, time and others for the production and assembly process. One way to evaluate the design of a product is with the Design for Manufacture and Assembly (DfMA). Some DFMA requirements can be used at various levels of complexity [4].

\section{Literature review}

\subsection{Standardization}

Standardization is the use of building components with a standard size of an integrated system that is carried out before the design stage including the installation process which has its own functions, models, sizes, procedures and other issues [5]. Standardization in the construction field is divided into two, i.e standardized products or components and also standardized processes [3]. Standardized products are to making various components needed in the plant for assembly at the construction site. While standardized processes by developing a process to handle unique aspects of a particular product in a location.

\subsection{Industrialization}

Industrialization is the process of development production system technology and its implementation using the standardization of design, mechanization and automation on site, computer equipment and mass

\footnotetext{
${ }^{*}$ Corresponding author: yanpurnomosafaa@ymail.com
} 
production of building elements [6]. Three main principles industrialization of construction are standardization, prefabrication and building systems [7].

Prefabrication is a technology in rapid construction of building by produce the main elements from a different place and delivered to location for installation [8]. Characteristics of prefabricated buildings are design standardization, industrial production and assembly construction [9]. Prefabrication is one of the answers in solve current building demands by re-produce products on a large scale for inventory and the speed of the building process [10].

\subsection{Definition, type and development of bridges in Indonesia}

Bridge is a structure built connecting two different locations, or facilitate traffic flow and across the lowlands. Based on constituent materials, bridges are divided into four type, i.e., wooden, steel, concrete and composite. There are currently 93000 bridges $(1138 \mathrm{~km})$ in Indonesia which consists of $72000(734 \mathrm{~km})$ in district or city and province roads with $21000(404 \mathrm{~km})$ in national roads which is dominated by mainly standard bridge, i.e., girder 51\% (comparison materials using concrete and steel are $75 \%: 25 \%$ ), culvert $7 \%$, truss $32 \%$ and others $10 \%$ [11].

The development of modern bridge construction at present meets the following requirements [12]:

- Achievment of connections between a composite steel and continous concrete for the elements.

- Minimized joints.

- Reduces installation time of elements.

- Minimize the problem of tolerance between concrete and steel materials.

- Suitable stiffness when receiving moments and deflection.

\subsection{Design for Manufacture and Assembly}

DfMA is a simultaneous design and engineering approach where the parts are manufactured and (sub-) assembled in a factory or warehouse, before being delivered to a construction site for installation [13]. DfMA using prefabricated techniques can provide benefits on construction schedules, costs, labour, safety and quality. The DfMA approach requires a change in the relationship between design and construction. The design focuses on the method which the project will be completed, where the possibility of using components is produced outside the site and logistics and assembly efficiency [14].

The main purpose of the DFMA is to assist designers in optimizing and increasing the success rate of prefabricated building design by integrating other stages of knowledge and information facilities into the design stage [9].

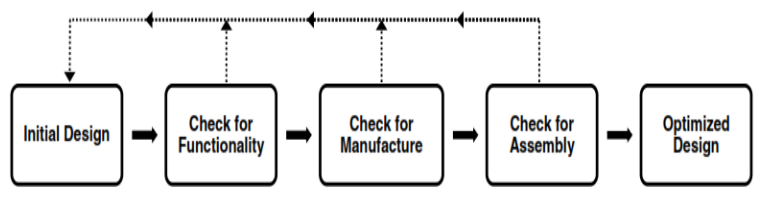

Fig. 1. DfMA procedure for a product [1]

\subsection{Relationship DfMA and lean construction}

Concepts lean construction is the production system adopted from the Japanese Toyota company with the principle that customer focus, culture, workplace organization and standardization, minimizing waste,continuous improvement and building quality [15]. Lean methods and tools are generally used for repetition of products such as the low variety of product series with large quantities [16]. The principle of lean production is also potentially implemented with the use of DfMA by simplifying the design and standardization of parts compared to conventional production systems which often occur rapidly [17]. The construction industry can be said to be a manufacturing process where the unification of materials forms a component for final installation. Lean construction is a major way to prevent large amounts of information lost in planning, factory production and development [18].

\section{Research methodology}

In this study the primary data from questionnaires, interviews and observation in the field. Whereas secondary data from catalogs of precast concrete product and the documents of bridge project. Respondents in this study are engineers who work on precast concrete companies. The first step of the study is given the DfMA category for bridges based on references which related to the standardized of bridge design in Indonesiain where show on Table 1.

Table 1. Identification of DfMA criteria and standardized of bridge design

\begin{tabular}{|l|c|c|c|c|c|c|c|c|c|}
\hline \multirow{2}{*}{ DfMA criteria (8); (11) } & \multicolumn{5}{|c|}{ Standarized of bridge design (10) } \\
\cline { 2 - 9 } & SS & D & I & M & R & E & C & A & L \\
\hline Simplicity of design & $\checkmark$ & $\checkmark$ & $\checkmark$ & $\checkmark$ & $\checkmark$ & $\checkmark$ & $\checkmark$ & $\checkmark$ & $\checkmark$ \\
\hline Number of components & $\checkmark$ & $\checkmark$ & $\checkmark$ & $\checkmark$ & $\checkmark$ & $\checkmark$ & $\checkmark$ & & $\checkmark$ \\
\hline Standardization on elements or material & $\checkmark$ & $\checkmark$ & $\checkmark$ & $\checkmark$ & $\checkmark$ & $\checkmark$ & $\checkmark$ & $\checkmark$ & $\checkmark$ \\
\hline Ease of handling & & & $\checkmark$ & & $\checkmark$ & $\checkmark$ & $\checkmark$ & & $\checkmark$ \\
\hline
\end{tabular}

SS = Structural Safety; D = Durability; I = Inspectability, M = Maintability; R = Rideability, E = Economical; C = Constructability; $\mathrm{A}=$ Aesthetics; $\mathrm{L}=$ Environment 
Table 2. Types, section and sizes of girder and slab bridge products [19]

\begin{tabular}{|c|c|c|c|c|c|}
\hline Name of product & Section & Type & Span (m) & Width (m) & Height (m) \\
\hline PC Double Tee Slab & & Slab & Variation & $1.65-2.1$ & 0,36 \\
\hline PC Full Slab & - & Slab & Variation & Variation & Variation \\
\hline PC U Girder & Girder & $13-42$ & $1-1,90$ & $1,20-1,85$ \\
\hline PC I Girder & Girder & $10-52$ & $0,35-0,8$ & $0,9-2,3$ \\
\hline PC T Girder & - & Girder & $25-30$ & $0,7-0,8$ & $1.4-2.3$ \\
\hline PC Voided Slab & - & Girder & $5-17$ & $0,91-1,2$ & $0.57-0.74$ \\
\hline PC Box Girder & - & Girder & $20-50$ & 8.75 & $2,4-2,5$ \\
\hline
\end{tabular}

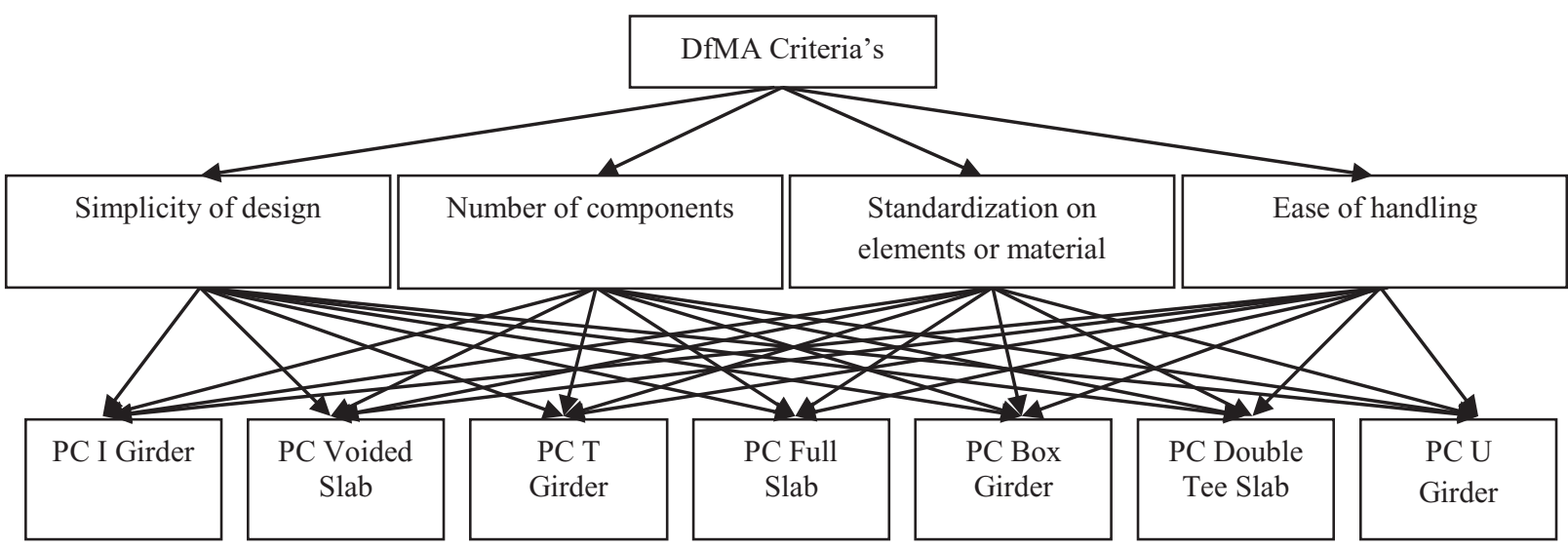

Fig. 2. Hierarchy structure of DfMA criteria's for precast products

\subsection{The assesment of precast products design}

The assessment product used in this study where the selection of precast concrete product designs on the girder and slab bridge elements that are often used so that evaluations can be carried out. These elements, are the main components in the building structure of the bridge. Table 2 shows the mapping of precast concrete products for bridge elements i.e. girder and slab. These products are assessed by the designers using the predefined DfMA criteria. In Figure 1 shows the hierarchy structure of an alternative product evaluation scheme consisting of four DfMA criteria combined with types of precast concrete products for the girder and slab bridge elements.

From the data obtained, then to measure the weight of the criteria and find out the final design score of each product, an analysis is done using analythical hierarchy process.

\subsection{Evaluation case study}

Evaluation was carried out on the construction of a bridge. The process includes identifying bridge components, redesign the bridge using precast product development, DfMA analysis, comparing the amount of costs, implementation time and knowing the impact of risk that happened.

\section{Data analysis and discussion}

\subsection{Analytical hierarchy process}

Table 3. Value geomean of each criteria

\begin{tabular}{|c|c|c|c|c|}
\hline \multirow{2}{*}{ Criteria } & \multicolumn{4}{|c|}{ R1, R2, R3, R4, R5, R6, R7, R8 } \\
\cline { 2 - 5 } & DS & JKK & SEM & KP \\
\hline SD & 1.00 & 1.28 & 0.49 & 0.56 \\
\hline NC & 0.78 & 1.00 & 0.31 & 0.52 \\
\hline SEM & 2.05 & 3.27 & 1.00 & 4.08 \\
\hline EH & 1.79 & 1.91 & 0.24 & 1.00 \\
\hline$\Sigma$ & 5.63 & 7.45 & 2.04 & 6,17 \\
\hline
\end{tabular}

$\mathrm{R} 1=$ Respondent $1 ; \mathrm{R} 2=$ Respondent 2; R3 = Respondent 3; $\mathrm{R} 4=$ Respondent 4; R5 $=$ Respondent 5; R6 $=$ Respondent 6 ; $\mathrm{R} 7=$ Respondent 7; R8 $=$ Respondent $8 ; \mathrm{SD}=$ Simplicity of design; $\mathrm{NC}=$ Number of components; SEM = Standardization on elements or materials; $\mathrm{EH}=$ Ease of handling

Table 4. Normal pairwise comparison matrix

\begin{tabular}{|c|c|c|c|c|c|c|}
\hline Criteria & SD & NC & SEM & EH & Weight & Average \\
\hline SD & 0,18 & 0,17 & 0,24 & 0.09 & 0.68 & 0.17 \\
\hline NC & 0,14 & 0,13 & 0,15 & 0,09 & 0.51 & 0.13 \\
\hline SEM & 0,36 & 0,44 & 0,49 & 0.66 & 1.96 & 0.49 \\
\hline EH & 0,32 & 0,26 & 0,12 & 0.16 & 0.86 & 0.21 \\
\hline
\end{tabular}

Average calculation the geometric (geomean) of each criterion is presented in table 3 , while the normal matrix analysis of paired comparisons includes calculating the weight of the most influential criteria and the average values shown in table 4.

From the results of the weighting criteria, the order of weight values from highest to lowest is 
standardization on elements or materials - ease of handling - simplicity design - number of components.

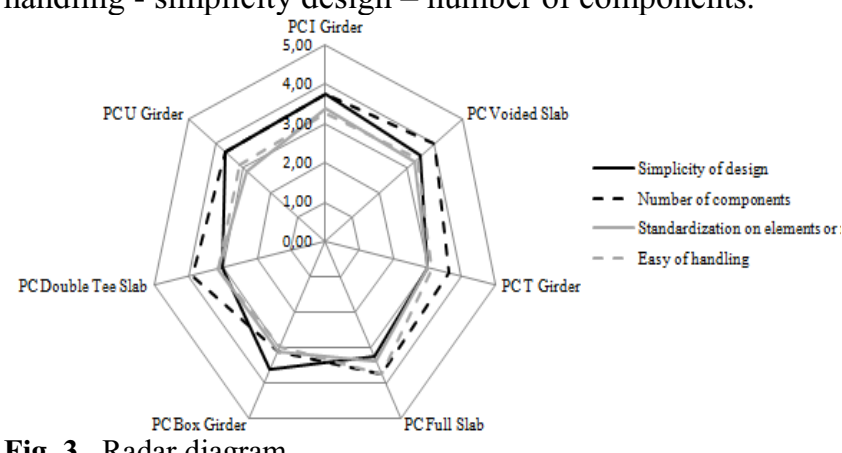

Figure 2 shows the radar diagram of the DfMA value of each product. The criteria value of each product varies between 3 to 4 . Although each product has the same manufacturing location in the factory, but in design there are several parameters that must be considered. Requirements for production taken by the designer specifically are the determination of size, material requirements, transportation to the location, prestressed systems, guidelines and others. Whereas in terms of the assembly process several reasons for product selection such as conditions in the project environment, bridge span, assembly method, guidelines and so on.

Fig. 3. Radar diagram

Table 5. The ranking of product design

\begin{tabular}{|c|c|c|c|c|c|c|c|c|c|c|c|c|c|c|c|}
\hline \multirow{3}{*}{ Criteria } & \multirow{3}{*}{ Weight } & \multicolumn{14}{|c|}{ Products } \\
\hline & & \multicolumn{2}{|c|}{ PC I Girder } & \multicolumn{2}{|c|}{$\begin{array}{c}\text { PC Voided } \\
\text { Slab }\end{array}$} & \multicolumn{2}{|c|}{$\begin{array}{l}\text { PC T } \\
\text { Girder }\end{array}$} & \multicolumn{2}{|c|}{$\begin{array}{l}\text { PC Full } \\
\text { Slab }\end{array}$} & \multicolumn{2}{|c|}{$\begin{array}{c}\text { PC Box } \\
\text { Girder }\end{array}$} & \multicolumn{2}{|c|}{$\begin{array}{l}\text { PC Double } \\
\text { Tee Slab }\end{array}$} & \multicolumn{2}{|c|}{ PC U Girder } \\
\hline & & Value & Score & Value & Score & Value & Score & Value & Score & Value & Score & Value & Score & Value & Score \\
\hline DS & 0,17 & 3,75 & 0,64 & 3,50 & 0,59 & 3,00 & 0,51 & 3,25 & 0,55 & 3,63 & 0,61 & 3,00 & 0,51 & 3,63 & 0,61 \\
\hline JKK & 0,13 & 3,38 & 0,43 & 3,25 & 0,41 & 3,00 & 0,38 & 3,38 & 0,43 & 3,13 & 0,40 & 3,13 & 0,40 & 2,88 & 0,37 \\
\hline SEM & 0,49 & 3,75 & 1,83 & 4,00 & 1,96 & 3,63 & 1,77 & 3,75 & 1,83 & 3,13 & 1,53 & 3,88 & 1,90 & 3,63 & 1,77 \\
\hline $\mathrm{KP}$ & 0,21 & 3,25 & 0,70 & 3,38 & 0,72 & 3,13 & 0,67 & 3,75 & 0,80 & 3,00 & 0,64 & 3,13 & 0,67 & 3,13 & 0,67 \\
\hline \multicolumn{2}{|c|}{ Total } & & 3,60 & & 3,69 & & 3,33 & & 3,62 & & 3,18 & & 3,47 & & 3,42 \\
\hline \multicolumn{2}{|c|}{ Ranking } & & 3 & & 1 & & 6 & & 2 & & 7 & & 4 & & 5 \\
\hline
\end{tabular}

Overall, from the results of the analysis and evaluation, the design values of each precast concrete product for the girder and bridge floor elements from the largest to the smallest respectively are PC Voided Slab PC Full Slab - PC I Girder - PC Double Tee Slab - PC U Girder - PC T Girder - PC Box Girder. This means that the designs of existing precast products, especially PC Voided Slab, are the closest to the principle Design for Manufacture and Assembly (DfMA). But it does not rule out the possibility that the value of other precast products can be better than those that already exist or are even superior. This happens if the designers take the initiative to revise design of the product in question, considering the value obtained is not much different. With the design change, it is hoped that it can create new types of products that make the production and assembly process easier in the factory or project environment.

\subsection{Sanjoyo River Bridge}

The construction of Sanjoyo River Bridge is part of the work package for construction of the Semarang-Solo toll road phase II Bawen-Solo section III Bawen-Salatiga located at sta. $34+321,870$ to sta. $34+498,735$ and the administrative area is located in Sukoharjo urban village, Pabelan sub-district, Semarang regency, Central Java province. The design of bridge is fully entrusted to PT. Citra Strada by adopting the DfMA approach on several components of the upper structure, while the work process is carried out by PT. PP (Persero) Tbk with a period time of 1,1 years. The design of bridge to be slightly curved with structure type monolith precast girder. The span of bridge is divided into five, i.e $25,6+$ $40,8+40,8+40,8+25,6=173,6 \mathrm{~m}$ and a total width of $25,2 \mathrm{~m}$. At each span each rests on the bearing where the tip of the bridge is above the abutment, while the pedestal in the span is being used by the crosshead of the pillars as a support for the main structure. The type of bridge foundation itself are bor piles on both abutments, while the pillars use a combination of foundation bor piles and footing.

In order to obtain an economical bridge design, it is necessary to re-select the girder cross section. In this case the dimensions of the beam determine efficiency of the components in the bridge structure, because it functions as a link to the main work loads on the upper structure to the lower structure. On bridges with simple spans, beam eccentricity is proportional to the prestressing force required where the moment acting in the middle can determine the design. Therefore due to greater eccentricity, more concrete area is needed on the top of the beam. This is recommended using " $T$ " or "I" beam section with wide wing characteristics. Both types of beams have a full cross-sectional standard at the end due to avoiding a zero value moment, increasing shear capacity and preventing failure in the anchorage area.

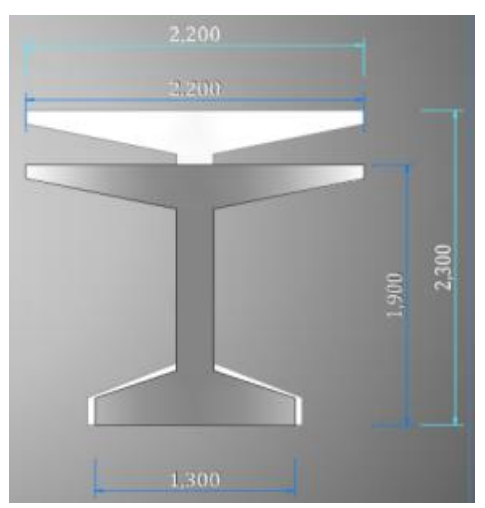

Fig. 4. Dimensions of the BH Girder [20] 
An alternative design for development the type of girder is now also carried out on one of the precast products that have a "T" section that is BH Girder. BH Girder is a combination of two types precast product, Bulb Tee Girder and Half Slab [20]. The principle of BH Girder in addition to reducing the amount of anchorage on the end of the beam and moving it to the middle. This product has several blisters, especially on the body of beam with a pre-stressed internal system. Half Slab on $\mathrm{BH}$ Girder has the principle of reducing the amount of thickness of the slab and also serves as a channel for the load to the girder so that it is more evenly distributed.

\subsubsection{Analysis of simplicity design}

The design of bridge uses standard sizes BH Girder with a span configuration of $57,8+58+57,8=173,6 \mathrm{~m}$. The distance between girders is optimized to $2,5 \mathrm{~m}$. Dimensions BH Girder i.e. ; 2,3 $\mathrm{m}$ high; widths upper flange 2,2 $\mathrm{m}$ and below 1,4 $\mathrm{m}$. Half Slab on BH Girder is designed as thickness $13 \mathrm{~cm}$. K-850 concrete quality specifications are used in girder to support bridge service life with several planning assumptions. Slab has a height of $15 \mathrm{~cm}$ and uses K-350 concrete quality with a main reinforcement using D22 - $120 \mathrm{~mm}$, while for reinforcement using D16 - $120 \mathrm{~mm}$. Slab divided into 3 rigid pavement segments according to the distribution of bridge span and includes one way slab type.

Table 6. Amount of elements

\begin{tabular}{|c|c|c|c|c|c|c|}
\hline \multirow{2}{*}{ Elements } & \multirow{2}{*}{ Material type } & \multirow{2}{*}{$\begin{array}{c}\text { Symbol } \\
\text { of Unit }\end{array}$} & \multicolumn{2}{|c|}{ Design } & \multirow{2}{*}{ Difference } & \multirow{2}{*}{$\begin{array}{c}\text { Efficiency } \\
(\%)\end{array}$} \\
\hline & & & Existing & Simulation & & \\
\hline \multirow{3}{*}{ Bearing } & Reinforced concrete & $\mathrm{m}^{3}$ & 4,83 & 12,10 & $(7,26)$ & $(150)$ \\
\hline & Fabrication of bearing & unit & 90,00 & 60,00 & 30,00 & 33,33 \\
\hline & Fabrication of rubber sheet & $\mathrm{m}^{2}$ & 62,92 & - & 62,92 & 100,00 \\
\hline Diaphragm & Precast concrete & unit & 341,00 & 243,00 & 98,00 & 28,74 \\
\hline Girder & Precast concrete & unit & 60,00 & 30,00 & 30,00 & 50,00 \\
\hline \multirow{3}{*}{ Slab } & Fabrication of spandeck & $\mathrm{m}^{2}$ & 255,84 & - & 255,84 & 100,00 \\
\hline & Fabrication of deck drain & unit & 78,00 & 68,00 & 10,00 & 12,82 \\
\hline & Reinforced concrete & $\mathrm{m}^{3}$ & 1093,68 & 656,21 & 262,48 & 24,00 \\
\hline Expansion joint & Fabrication & $\mathrm{m}$ & 152,50 & 105,00 & 47,50 & 31,15 \\
\hline
\end{tabular}

Finally, for diaphragm beams in the transverse position designed with a system precast that has a length of 2,28 m; width of $2 \mathrm{~m}$ and a thickness of $0,2 \mathrm{~m}$. Each span has 90 plate pieces with some stressing bars. In table 6 shows the needs of the elements of each design. The five elements in the simulation design have efficiency of $28,83 \%$ compared to existing design.

\subsubsection{Analysis of components quantity and the use of standardization on elements or material}

The difference in design of a bridge element also results in changes in the amount of constituent components and standardization of elements or materials. The bridge component consists of several sets of materials arranged to form a bridge element.

Table 7. Comparison of components quantity

\begin{tabular}{|c|c|c|c|c|c|c|}
\hline \multirow[b]{2}{*}{ Elements } & \multirow[b]{2}{*}{ Components } & \multirow{2}{*}{$\begin{array}{l}\text { Symbol } \\
\text { of Unit }\end{array}$} & \multicolumn{2}{|c|}{ Design } & \multirow[b]{2}{*}{ Difference } & \multirow{2}{*}{$\begin{array}{c}\text { Efficiency } \\
(\%)\end{array}$} \\
\hline & & & Existing & Simulation & & \\
\hline \multirow{7}{*}{ Bearing } & Deformed bar & $\mathrm{kg}$ & 1108.65 & 2784.02 & $(1675.37)$ & $(151.12)$ \\
\hline & Metal bearing shoe type A & unit & 24.00 & 60.00 & $(36.00)$ & $(150.00)$ \\
\hline & Bearing pad size $(30 \times 35 \times 0.36 \mathrm{~cm})$ & unit & 12.00 & - & 12.00 & 100.00 \\
\hline & Bearing pad size $(35 \times 40 \times 0.39 \mathrm{~cm})$ & unit & 48.00 & - & 48.00 & 100.00 \\
\hline & Bearing pad size $(30 \times 35 \times 0.36 \mathrm{~cm})$ & unit & 6.00 & - & 6.00 & 100.00 \\
\hline & Rubber sheet & $\mathrm{m}^{2}$ & 62.92 & - & 62.92 & 100.00 \\
\hline & Mortar and grouting & $\mathrm{m}^{3}$ & 4.84 & 12.01 & $(7.26)$ & $(150.00)$ \\
\hline \multirow{6}{*}{ Diaphragm } & Round bar & $\mathrm{kg}$ & 171.03 & 452.45 & $(281.42)$ & $(164.54)$ \\
\hline & Deformed bar & $\mathrm{kg}$ & 25464.57 & 39873.01 & $(14408.44)$ & $(56.58)$ \\
\hline & Ducting & bh & 682.00 & 486.00 & 196.00 & 28.74 \\
\hline & Concrete class B1 & $\mathrm{m}^{3}$ & 148.85 & 173.60 & $(24.75)$ & $(16,63)$ \\
\hline & Bar & unit & 31.00 & 27.00 & 4.00 & 12.90 \\
\hline & Widges plate and accessories & unit & 62.00 & 42.00 & 20.00 & 32.26 \\
\hline \multirow{10}{*}{ Girder } & Deformed bar & $\mathrm{kg}$ & $314,613.51$ & $347,925.72$ & $(33312,21)$ & $(10,59)$ \\
\hline & Bursting steel & unit & 216.00 & 150,00 & 66,00 & 30,56 \\
\hline & Spiral & unit & 216,00 & 150,00 & 66,00 & 30,56 \\
\hline & Upper dowel & unit & 21180,00 & 15390,00 & 5790,00 & 27,34 \\
\hline & Tendon pipe & point & 1080.00 & 900.00 & 180.00 & 16.67 \\
\hline & Blister & point & 360.00 & 300.00 & 60.00 & 16.67 \\
\hline & Concrete class A1 & $\mathrm{m}^{3}$ & 1394.12 & 2283.19 & $(889.07)$ & $(63.77)$ \\
\hline & Shear connector between segments & unit & 504.00 & 0.00 & 504.00 & 100,00 \\
\hline & Adhesive connection between segments & point & 720.00 & 900.00 & $(180.00)$ & $(25.00)$ \\
\hline & Strand & unit & 216.00 & 150.00 & 66.00 & 30.56 \\
\hline
\end{tabular}




\begin{tabular}{|c|l|c|r|r|r|r|}
\hline \multirow{5}{*}{} & Prestressed wire & unit & 3216.00 & 7110.00 & $(3894.00)$ & $(121.08)$ \\
\cline { 2 - 6 } & Live anchorage & unit & 60.00 & 30.00 & 30.00 & 50.00 \\
\cline { 2 - 7 } & Died end anchorage & unit & 60.00 & 30.00 & 30.00 & 50.00 \\
\cline { 2 - 7 } & Cables cover and accessories & unit & 120.00 & 60.00 & 60,00 & 50,00 \\
\cline { 2 - 7 } & Grouting & $\mathrm{m}^{3}$ & 0,20 & 0,10 & 0,10 & 50,00 \\
\hline \multirow{5}{*}{ Slab } & Bondeck & $\mathrm{m}^{2}$ & 255,84 & 0,00 & 255,84 & 100,00 \\
\cline { 2 - 7 } & Screws of bondeck & unit & 1736,00 & 0,00 & 1736,00 & 100,00 \\
\cline { 2 - 7 } & Deformed bar & $\mathrm{kg}$ & 209270.43 & 244151.65 & $(34881.22)$ & $(16.67)$ \\
\cline { 2 - 7 } & Deck drain & unit & 78.00 & 68.00 & 10.00 & 12.82 \\
\cline { 2 - 7 } & Concrete class B1 & $\mathrm{m}^{3}$ & 1093.68 & 656.21 & 437,47 & 40.00 \\
\hline \multirow{2}{*}{$\begin{array}{c}\text { Expansion } \\
\text { Joint }\end{array}$} & Seal joint & $\mathrm{m}$ & 152.50 & 0.00 & 152.50 & 100.00 \\
\cline { 2 - 7 } & Modular joint & $\mathrm{m}$ & 47.50 & 105.00 & $(57.50)$ & -121.05 \\
\hline
\end{tabular}

The use of standardization is a dimension, guideline and something that is repetitive to an element or material. Comparison of the quantity of components between existing design and simulation design are presented in Table 7. Based on the results mentioned, the use of $\mathrm{BH}$ Girder in the simulation design resulted in reduced volume of material in each elements, with savings of $8,74 \%$ compared to the existing design using PC I Girder.

\subsubsection{Analysis ease of handling}

One of the principles of DfMA is to reduce the amount of step works from the production and assembly line. The steps of production and assembly of a bridge element are various activities from the manufacturing process to the interrelated installation. The steps of bridge construction work are focused on assembly lines in this case the construction project as the estuary from the completion of a final product.

Table 8. List the detail of works

\begin{tabular}{|l|c|c|}
\hline \multicolumn{1}{|c|}{ Work items } & ED & SD \\
\hline Bearing pad size. $(300 \times 350 \times 36 \mathrm{~mm})$ & A & - \\
\hline Bearing pad size $(350 \times 400 \times 39 \mathrm{~mm})$ & B & - \\
\hline Bearing pad size $(450 \times 450 \times 39 \mathrm{~mm})$ & C & - \\
\hline Rubber sheet & D & - \\
\hline Metal bearing shoe type A & E & A \\
\hline PC I Girder span $40,8 \mathrm{~m}(\mathrm{H}=160 \mathrm{~cm})$ & F & - \\
\hline PC I Girder span $25,6 \mathrm{~m}(\mathrm{H}=210 \mathrm{~cm})$ & G & - \\
\hline BH Girder span $58 \mathrm{~m}(\mathrm{H}=230 \mathrm{~cm})$ & - & B \\
\hline Round bar & H & C \\
\hline Concrete class B-1-2 (diaphragm) & I & D \\
\hline Plate precast (concrete plate $)$ & J & - \\
\hline Deform bar & K & E \\
\hline Concrete class B-1-1 $($ RC deck slab $)$ & L & F \\
\hline Expansion joint type C2 & M & G \\
\hline Expansion joint type G & N & H \\
\hline
\end{tabular}

$\mathrm{ED}=$ Existing design; $\mathrm{SD}=$ Simulation design

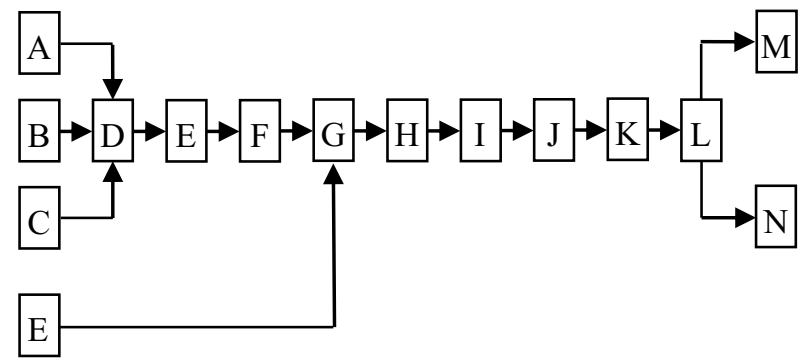

Fig. 5. Network diagram of existing design

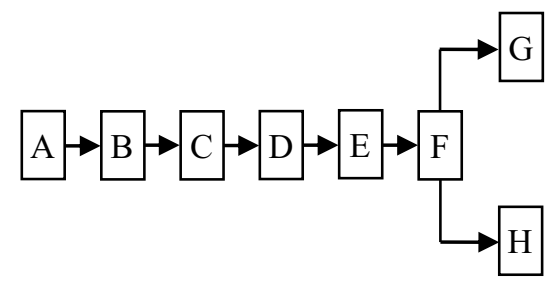

Fig. 6. Network diagram of simulation

In table 8 shows a list of concrete structure works between existing design and simulation design. Based on the results of analysis using a list of work details and network diagrams, it can be concluded that number of stages in simulation design is less than existing design. The efficiency that arises from this is $25 \%$. So that with this reduction resulting in a control process in terms of handling work can be done more easily.

\subsubsection{Analysis of productivity and DfA Index}

Design for assembly (DfA) index is a result of multiplication between the sum of the minimum theoretical parts and the basic assembly time of each component divided by the total installation time as a whole. At this stage the DfA index is focused on the time of installation of the girder bridge. Analysis of productivity and time duration is carried out through field observations with the intention that the data obtained is more accurate and in accordance with the actual conditions. Before carrying out the analysis phase, it is necessary to look back at the method of installing the bridge girder in the existing design i.e crane and gantry system. Then one of them is chosen as a comparison.

Table 9. Assembliy time of crane methods

\begin{tabular}{|c|c|}
\hline Steps & Time (minutes) \\
\hline Preparation & 13,60 \\
\hline Lifting & 0,21 \\
\hline Swing & 0,70 \\
\hline Placement at position & 43,4 \\
\hline Return to location of loading & 12,00 \\
\hline+2 & 69.91 \\
\hline
\end{tabular}

The result of calculation of each time of installation stage of the girder using the crane is shown in table 9. The total time for the assembly process of one girder unit is 69,91 minutes with the average time to the five steps is 13,98 minutes. By considering the next stage, namely the installation of diaphragm beam, normal working time 8 
hours (480 minutes/day) and other activities on the project after installation of the girder, the daily productivity is taken 2 units.

Table 10. Assembly time of gantry method

\begin{tabular}{|l|l|r|}
\hline \multicolumn{1}{|c|}{ Steps } & Tools & Time (minutes) \\
\hline Preparation & Crane & 13,60 \\
\hline Transportation & Crane & 0,21 \\
\hline Swing & Crane & 0,70 \\
\hline Placements of launcher & Crane & 8,30 \\
\hline Attribution for decision & Gantry & 2,30 \\
\hline Cargo and decreased & Gantry & 32,10 \\
\hline Release & Gantry & 1,20 \\
\hline Return to the location of loading & Gantry & 6,40 \\
\hline \multicolumn{2}{|c|}{$\Sigma$} & 64,81 \\
\hline
\end{tabular}

In table 10 shows the duration time of each girder installation steps using launching gantry method which consists of two main tools i.e crane and gantry. Total time for the assembly of one girder unit is 64,81 minutes, while the average value has 8,1 minutes. In launching gantry method, activity under span of bridge can be carried out smoothly because it does not prevent crane method from requiring enough a large area. From these considerations, the daily productivity of the girder installation is 3 units.

Table 11. Calculation DfA Index

\begin{tabular}{|c|c|c|c|c|c|c|c|}
\hline \multirow{2}{*}{ Design } & \multirow{2}{*}{ Method } & \multicolumn{6}{|c|}{ Parameters } \\
\cline { 3 - 8 } & & $\mathbf{p}$ & $\mathbf{q}$ & $\mathbf{r}$ & $\mathbf{s}$ & $\mathbf{t}$ & $\mathbf{u}$ \\
\hline \multirow{2}{*}{ Existing } & Crane & 24 & 69,905 & 11,041 & 1677,731 & 0,158 & \multirow{2}{*}{0,164} \\
\cline { 2 - 8 } & Gantry & 36 & 64,805 & 11,041 & 2332,996 & 0,170 & \\
\hline Simulation & Gantry & 30 & 64,805 & 11,041 & 1944,163 & 0,170 & 0,170 \\
\hline
\end{tabular}

$\mathrm{p}=$ Amount of girder needs (units); $\mathrm{q}=$ Time for unit assembly girder (minutes); $r=$ Basic assembly time of each component stage (minutes); $\mathrm{s}=$ Total assembly girder time (minutes) $=\mathrm{p} \mathrm{x}$ $\mathrm{q} ; \mathrm{t}=$ DfA Index (\%); $\mathrm{u}=$ Average value.

Table 11 is a summary of the overall duration of installation of the girder and the DfA index value in each design. All segments PC I Girder requires 4010,727 minutes, while BH Girder 1944,163 minutes means that there is $51,53 \%$ efficiency in assembly time. Based on these results it can also be seen that the amount of days time of girder installation is 10 days in the simulation design and 24 days in the existing design. The value DfA index is $0,164 \%$ for the existing design and $0,17 \%$ for the simulation design. By looking at these conditions, it can be concluded that the simulation design has an assembly index value that is better than the existing design.

\subsubsection{Analysis of time}

Analysis of time functions to determine the number of settlement days work. Bar chart is used to measure the calculation of the duration of the activity . Determination of the number of days for each work item based on several parameters such as work volume, method of works, number of stages of parts, type of material used, weather, location and others. Overall for the duration of the work execution time there is efficiency 10 days or $18,87 \%$.

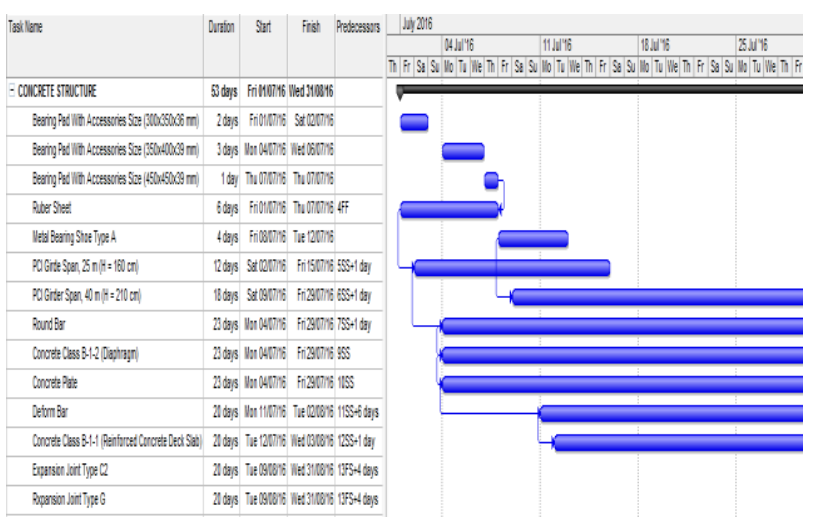

Fig. 7. Bar chart the works of existing design

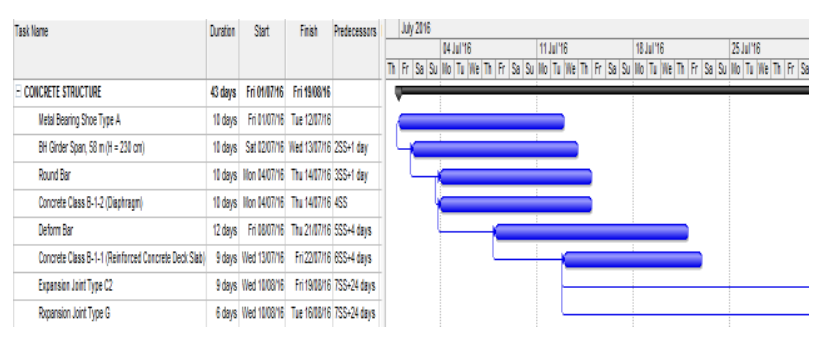

Fig. 8. Bar chart the works of simulation design

\subsubsection{Analysis of cost}

Cost analysis is done to determine the total price of each work item. The calculation is focused on the direct costs of work obtained from the multiplication between the volume of work and the unit price. For unit prices that are not in the bill of quantity such as BH girder, then the technical analysis of unit prices is done manually.

Table 12 shows total cost the works of existing design is Rp. 24.241.735.772,02 while the works of simulation design is Rp. 18.571.014.244,83. One of the works that is the factor that causes the difference in the costs is the girder with a value of Rp. 2215181274.21. Based on these results overall it can be concluded that there is a reduction in costs with a percentage of $23.39 \%$.

Table 12. Total cost of concrete structure work

\begin{tabular}{|l|r|r|r|r|}
\hline \multirow{2}{*}{ Works } & \multicolumn{2}{|c|}{ Design } & \multirow{2}{*}{ Difference (Rp.) } & \multirow{2}{*}{ Efficiency (\%) } \\
\cline { 2 - 3 } & \multicolumn{1}{|c|}{ Existing (Rp.) } & \multicolumn{1}{|c|}{ Simulation (Rp.) } & \\
\hline Concrete class B-1-1 (RC deck slab) & 1894253760.00 & 1136552256.00 & 757701504.00 & 40.00 \\
\hline Concrete class B-1-2 (Diaphragm) & 284265785,51 & 331527600,22 & $(47261814.71)$ & $(16.63)$ \\
\hline Round bar & 1697492.60 & 4490566.25 & $(2793073,65)$ & $(164,54)$ \\
\hline Deformed bar & 5340913995,25 & 3128998652,57 & 2211915342,68 & 41,41 \\
\hline PCI Girder spans 25 m (H=160 cm) & 3644572032,00 & - & 3644572032,00 & 100,00 \\
\hline
\end{tabular}




\begin{tabular}{|c|c|c|c|c|}
\hline \multirow{2}{*}{ Works } & \multicolumn{2}{|c|}{ Design } & \multirow{2}{*}{ Difference (Rp.) } & \multirow{2}{*}{ Efficiency (\%) } \\
\hline & Existing (Rp.) & Simulation (Rp.) & & \\
\hline PCI Girder spans $40 \mathrm{~m}(\mathrm{H}=210 \mathrm{~cm})$ & 11359688472,00 & - & 11359688472.00 & 100.00 \\
\hline BH Girder spans $58 \mathrm{~m}(\mathrm{H}=230 \mathrm{~cm})$ & - & 12789079229.79 & $(12789079229.79)$ & $(100.00)$ \\
\hline Concrete Plate & 66772704,96 & - & 66772704.96 & 100.00 \\
\hline Expansion joint type $\mathrm{C} 2$ & 569512545,00 & 284756272,50 & 284756272,50 & 50,00 \\
\hline Expansion joint type $\mathrm{G}$ & 535632467,50 & 535632467,50 & - & - \\
\hline Metal bearing shoe type A & 143990880,00 & 359977200,00 & $(215986320.00)$ & $(150,00)$ \\
\hline Bearings pad size. $(300 \times 350 \times 36 \mathrm{~mm})$ & 21063876.00 & - & 21063876.00 & 100.00 \\
\hline Bearing pad size $(350 \times 400 \times 39 \mathrm{~mm})$ & 114422208.00 & - & 114422208.00 & 100.00 \\
\hline Bearing pad size $(450 \times 450 \times 39 \mathrm{~mm})$ & 20268774.00 & - & 20268774.00 & 100.00 \\
\hline Ruber sheet & 244680779,20 & - & 244680779,20 & 100,00 \\
\hline$\Sigma$ & 24241735772,02 & 18571014244,83 & 5670721527,19 & 23.39 \\
\hline
\end{tabular}

\subsubsection{Risk management}

The change of bridge element design also have an impact on the value of the risk received. Application DfMA to the bridge construction, also attempts to move most of activities in the field into factory conditions. The risks such as weather conditions, and work safety are reduced.

\section{Conclusions and recommendation}

The design of bridges in Indonesia, it must meet several standard requirements. Some DfMA criteria can be used in the construction of bridge elements both in the factory environment or construction projects. There are seven precast concrete products for girder and slab bridge elements to use and further development. In the case study, one of the precast concrete products developed from the development was applied to a bridge design. The results of DfMA analysis, costs, time and risk management show that the simulation design using development products can provide efficiency better than existing designs. The construction company can cooperate with universities for research and development building components. For employment contracts, it is necessary to give more authority to specialist contractors (installation, special construction and prefabricated construction) in the system of design, engineering, procurement and implementation. Finally, the use of integral and prefabricated bridge concepts needs to be combined with DfMA for further research.

\section{References}

1. K. Min Koo, S. McGovern, M. Belsky, C. Middleton, and I. Brilakis, A Suitability Analysis of Precast Components for Standardized Bridge Construction in the United Kingdom, Proc. Eng., 164, 188-95 (2016)

2. FHWA, Accelerated Bridge Construction, TRL: https://www.fhwa.dot.gov/bridge/prefab/girder, (2018)

3. A. Aapaoja and H. Haapasalo, The Challenges of Standardization of Products and Processes in Construction, 22 983-93 (2014)
4. M. Kalyun, and T. Wodajo, Application of a Design Method for Manufacture and Assembly, Master of Science Thesis Chalmers University of Technology Sweden, (2012)

5. B. Yasin Al and A. Rjoub Al, Standardization in Construction as a Tool to Reduce Cost of Housing for the Low-Income Families in Jordan, J. of Civ. Eng. and Arch., 11, 141-148 (2017)

6. J. Zhang, Y. Long, S. Lv, and Y. Xiang. BIMEnabled Modular and Industrialized Construction in China. Proc. Eng., 145, 1456-61 (2016)

7. M. Spišáková and M. Kozlovská. Lean Production as an Innovative Approach to Construction., J. Of Civ. Eng., 8, 87-96 (2013)

8. E. M. Generalova, V. P. Generalov, and A. A. Kuznetsova, Modular Buildings in Modern Construction. Proc. Eng. 153, 167-72 (2016)

9. Z. Yuan, C. Sun, and Y. Wang, Automation in Construction Design for Manufacture and Assembly-Oriented Parametric Design of Prefabricated Buildings, Auto. in Cons., 88, 13-22 (2018)

10. F. Pittau, L. E. Malighetti, G. Iannaccone, and G. Masera, Prefabrication as Large-Scale Efficient Strategy for the Energy Retrofit of the Housing Stock: An Italian Case Study., Proc. Eng., 180, 1160-69 (2017)

11. I. Imran, D. Hoedajanto, and I. Zarkasi, BRIDGES IN INDONESIA, JSCE Century Anniversary, (2014)

12. B. Briseghella, and T. Zordan, An Innovative SteelConcrete Joint for Integral Abutment Bridges, J. of Traf. and Trans. Eng., 2 , 209-22 (2015)

13. B. Anvari, P. Angeloudis, and W. Y. Ochieng, $A$ Multi-Objective GA-Based Optimisation for Holistic Manufacturing, Transportation and Assembly of Precast Construction, Auto. in Const., 71, 226-41 (2016)

14. Building and Construction Authority Singapore, BIM for DfMA (Design for Manufacturing and Assembly) Essential Guide, (2016)

15. E. P. Small, K. Al Hamouri, and H. Al Hamouri, Examination of Opportunities for Integration of Lean Principles in Construction in Dubai. Proc. Eng., 196, 616-21 (2017)

16. D. T. Matt, P. Dallasega, and E. Rauch, On-Site Oriented Capacity Regulation for Fabrication 
Shops in Engineer-to-Order Companies ( ETO), Proc. CIRP, 33, 197-202 (2015)

17. R. J. Schonberger, DFMA - A Potent Lean Methodology, www.assemblymag.com, (2015).

18. S. Pulakka, S. Vares, E. Nykänen, M. Saari and T. Häkkinen, Lean Production of Cost Optimal Wooden nZEB., Energ. Proc., 96 (2016) 202-11.

19. Wijaya Karya Beton, PT. Brocure the Precast Concrete Manufacture, (2017)

20. GS E\&C Corporation and Towoong E\&C, BH Girder Presentation in Jakarta, (2013)

21. BSN-National Standardization Agency of Indonesia, Introduction to Standardization $2^{\text {nd }}$ edition (In Bahasa), (2014).

22. Ministry of Public Work and People's Housing Republic of Indonesia, Standardized Design of Bridge (Indonesia Language), (2015)

23. Trans Marga Jateng, PT. Contract Addendum No. 3 Contractor Services Phase II Bawen-Solo Section III : Bawen-Salatiga Package Sanjoyo River Bridge (Sta. 34+100 - Sta. 34+900), (2016) 